\title{
DEVELOPMENT AND EVALUATION OF A TURFGRASS AERATION MACHINE
}

\author{
Nasr, G.M ${ }^{1}$.; Badawy, E.M ${ }^{2}$; Sharobeem, Y.F ${ }^{3}$, and Refai, M.A ${ }^{4}$.
}

\begin{abstract}
Turfgrass aeration involves the removal of small soil plugs or cores out of turfgrass. Most aeration is done mechanically with a machine having hollow tines or spoons mounted on a disk or drum. The objective of this study is to development, evaluation and manufactures an aeration machine for turfgrass. The evaluation study focused on measurements of soil bulk density, void ratio, soil porosity and energy consumption. The first three parameters were measured before and after turfgrass aeration with three tine diameters $(1.27,1.9$ and $2.54 \mathrm{~cm})$ under two depths (5 and $8 \mathrm{~cm}$ ) with three working forward speeds (1.5, 2 and $2.7 \mathrm{~km} / \mathrm{h}$.). Results showed that reduction in bulk densities in all treatments and the effective treatment was 0.78 at $8 \mathrm{~cm}$ depth, tine diameter $1.27 \mathrm{~cm}$ and forward speed $1.5 \mathrm{~km} / \mathrm{h}$. The void ratio increased for all treatments, while the highest increase value was 1.95 at $8 \mathrm{~cm}$ depth, tine diameter $1.27 \mathrm{~cm}$ and forward speed $1.5 \mathrm{~km} / \mathrm{h}$. and Soil porosity increased for all treatments, and the effective treatment from variance analysis was $66.09 \%$ with same treatment.it noticed that The highest values of field capacity was $0.687 \mathrm{fed} / \mathrm{h}$ with third diameter $2.54 \mathrm{~cm}$ at $5 \mathrm{~cm}$ depth with $2.7 \mathrm{~km} / \mathrm{h}$. It was found that the higher treatment in consumed fuel was the third diameter $(2.54 \mathrm{~cm})$ at $8 \mathrm{~cm}$ depth and $2.7 \mathrm{~km} / \mathrm{h}(5.78 \mathrm{~L} / \mathrm{h})$. It was found that $T_{1} d_{1} s_{3}$ (tine diameter $1.27 \mathrm{~cm}$, depth $5 \mathrm{~cm}$ and forward speed $2.7 \mathrm{~km}$ h) had the lower value energy consumption $22.84 \mathrm{~kW}$.h./fed.
\end{abstract}

\section{INDROUTION}

7 -urfgrass plants are normally perennial which grow through tillering, stolon and rhizomatous growth, and ideally, develop 1 new vegetative shoots continually throughout the year. (Lodge et al., 1990).

\footnotetext{
${ }^{1}$ Professor of Agricultural Engineering, Fac. Agric., Cairo University.

${ }^{2}$ Professor of Ornamental Horticulture, Fac. Agric., Cairo University.

${ }^{3}$ Head Res. of Agric. Eng., Agric. Eng. Res. Inst., Ministry of Agric.

${ }^{4}$ Demonstrator, Agric. Eng., Fac. Agric. Cairo University.
} 
Hillel (1980) described compaction as the process of soil densification or compression, which leads to the reduction of air volume in an unsaturated soil or water in a saturated soil Traffic from mowers, sprayers, golfers, and golf carts compact fairway soils. This traffic usually compacts the top 5 to $7.5 \mathrm{~cm}$ in turf situations with the top $2.5 \mathrm{~cm}$ being the most severely compacted (Beard, 1973).

Soil compaction is a problem in many turf areas (Sills and Carrow, 1983). Research has shown that soil compaction reduces water, heat, reduces root penetration, and gas exch0ange (Linn and Doran, 1984). Compacted soil restricts air and water movement to roots (Bruneau et al., 2004). (Meek et al., 1992) stated that a reduction in compaction can be achieved by applying traffic to the soil when it is as dry as possible. Compaction leads to decreased soil infiltrability (Akram and Kemper, 1979). decreased saturated hydraulic conductivity (Dawidowski and Koden, 1987) and decreased air entry values, while increased saturated water content (Libardi et al., 1976).

Cultivation/aeration is briefly defined as mechanically disturbing the rootzone or thatch layer by punching or slicing various types and depths of holes or fissures into turf surface to improve overall rootzone quality and turfgrass performance without destroying the turf (Bunnell et l., 2001).

Among other benefits, the two main objectives in aeration turfgrass systems are to remove thatch-mat and organic matter, to improve soil physical properties such as soil aeration, air-soil gas exchange, saturated hydraulic conductivity, and to reduce soil compaction (Sorokovsky et al., 2007).

Turgeon (2002) stated that Coring or core cultivation is the practice by which hollow tines or spoons are used to extract cores from the soil. Core size varies from 0.635 and $2.54 \mathrm{~cm}$ in diameter, depending on the size of the tine. The vertical length of the cores varies with soil strength and penetration capacity of the coring apparatus. Since soil strength is proportional to bulk density and moisture content, increasing soil moisture facilitates deeper penetration of the tines. Core lengths are 7.62 $\mathrm{cm}$. 
McCarty et al. (2007) reported that organic matter increased from 19 to $25 \mathrm{~g} \mathrm{~kg}-1$, a $32 \%$ increase, in the surface $5.1 \mathrm{~cm}$ of an uncultivated turfgrass system. Organic matter content was reduced from 20 to $18 \mathrm{~g} \mathrm{~kg}$ 1 , a $10 \%$ reduction, when turfgrass was core cultivated four times annually.

Abrougui et al. (2013) found that bulk density decreases after the aerator passage aeration, after aeration, the bulk density recorded a decrease compared to the initial state of 9 and $8 \%$. Soil resistance recorded a decrease compared to the initial state by 53 and $58 \%$.

\section{MATERIALS AND METODS}

The aim of this study is to development, evaluation and manufactures aeration machine for turfgrass with vertical motion to reduce turfgrass soil compaction. The machine depends on producing round vertical holes.

\section{MATERIALS:}

\section{a- The agricultural tractor:}

The characteristics of the agricultural tractor, used in this study as mobile power are $45 \mathrm{Hp}$ engine at 2200 r.p.m. and $2 * 4$ wheeled typed.

\section{b- Hand digital tachometer:}

The rotational speed of the machine was measured for the main shaft of the machine it was measured by using a hand digital photo / contact tachometer, The specifications of selected tachometer according to its instruction manual were with range 0.5to 19,999 r.p.m and accuracy $0.05 \%+1$ Digit.

\section{c- Soil resistance to penetration:}

The soil cone penetrometer is recommended as a measuring device to provide a standard uniform method of characterizing the penetration resistance of soils. The force required to press the $300 \mathrm{deg}$. circular cone through the soil, expressed in kilopascals (ASABE Standards, 2006). The specifications of selected tachometer according to its instruction manual are with Memory1500 measurements and Maximum penetration force $1000 \mathrm{~N}$. 


\section{d- Design of Aeration machine:}

The design of the aeration machine consist of the following main component as shown (fig.1), The machine consists of four parts including, frame and hitch (A), transmission system from tractor to machine with crankshaft and connecting $\operatorname{rod}(\mathrm{B})$, flexible linkage (C) and tines holder (D). The overall dimensions of aeration machine were $119 \times 55 \times 60 \mathrm{~cm}$.

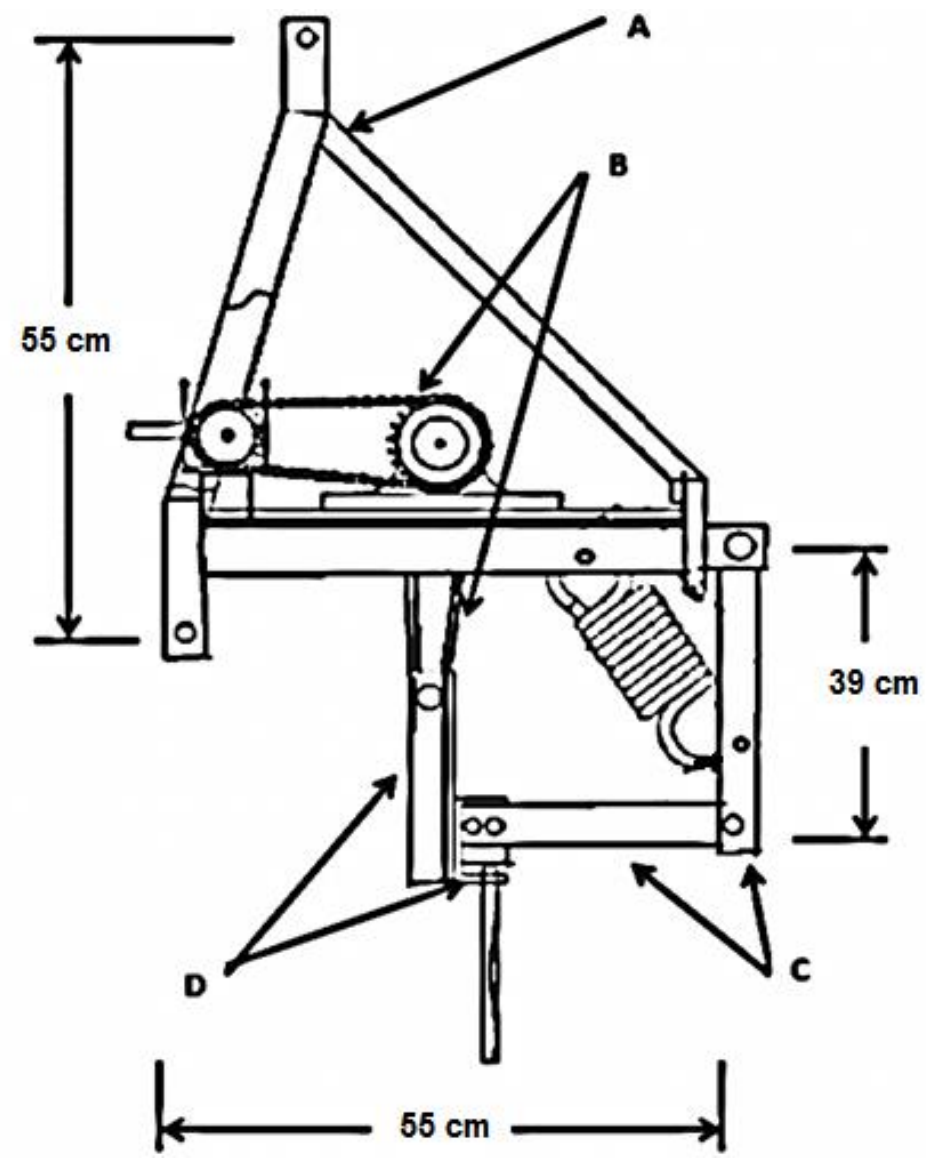

Fig.1.Side view of aeration machine.

The designing of turfgrass aerator machine depended on the results gathered from penetrating force and calculation for items of turfgrass aerator machine then manufacture the machine with bevel gear system, 
chain and sprocket, crank shaft, connection rod, bearing, tine holder, flexible linkage and core tine.

\section{1- Chain and sprocket:}

The chain transmits power between two rotating shafts by meshing with toothed sprockets was Calculated sprocket Diameter was by using the following formula according to (Shippen, 1980):

$$
\frac{N_{2}}{N_{1}}=\frac{R_{1}}{R_{2}}
$$

$\mathrm{N}_{1}=$ Rotating velocity of driving sprocket, r.p.m.

$\mathrm{N}_{2}=$ Rotating velocity of driven sprocket, r.p.m.

$\mathrm{R} 1=$ radius of driving sprocket, $\mathrm{cm}$.

$\mathrm{R} 2=$ radius of driven sprocket, $\mathrm{cm}$.

The chain length, in pitches, was calculated by using the following formula according to (Chaild, 2004):

$$
L=\frac{N_{1}+N_{2}}{2}+\frac{2 C}{P}+\left(\frac{N_{2}-N_{1}}{2 \pi}\right)^{2} \frac{P}{C}
$$

Where:

$\mathrm{L}=$ number of pitches, $\mathrm{m}$.

$\mathrm{N} 1=$ number of teeth, in the driving sprocket

$\mathrm{N} 2=$ number of teeth in the driven sprocket

$\mathrm{C}=$ center distance, $\mathrm{m}$.

$\mathrm{P}=$ chain pitch, $\quad \mathrm{m}$.

\section{2- Crank shaft :}

Crank shaft is one of the most important moving parts in first prototype aerator, which gives the reciprocating motion to tine holder.

\section{3- Connection rod:}

Connecting rod is used to transmit motion from crankshaft to core tine holder, its function is to transmit the movement of push and pull from the crankpin to the tine holder pin.

The pin diameter of connection rod with tine holder was calculated by following formula according to (Khurmi and Gupta, 2005): 


$$
\mathrm{F}_{\mathrm{t}}=\mathrm{d}_{\mathrm{c}} * \mathrm{l}_{\mathrm{c}} * \mathrm{P}_{\mathrm{bp}}
$$

Where:

$\mathrm{d}_{\mathrm{c}}=$ diameter of the pin of connection rod, $\mathrm{mm}$,

$\mathrm{l}_{\mathrm{c}}=$ length of the pin of connection rod, $\mathrm{mm}$.

$\mathrm{P}_{\mathrm{bp}}=$ Bearing pressure, $\quad 20 \mathrm{~N} / \mathrm{mm}^{2}$.

\section{4- Bearing :}

The term 'bearing' typically refers to contacting surfaces through which a load is transmitted. Bearings may roll or slide or do both simultaneously, the term 'sliding bearing' refers to bearings where two surfaces move relative to each other without the benefit of rolling contact.

\section{5- Tine Holder:}

The channel beam was used as the tine holder (fig.2), Beams are generally horizontal members which transfer loads horizontally along their length to the supports where the loads are usually resolved into vertical forces.

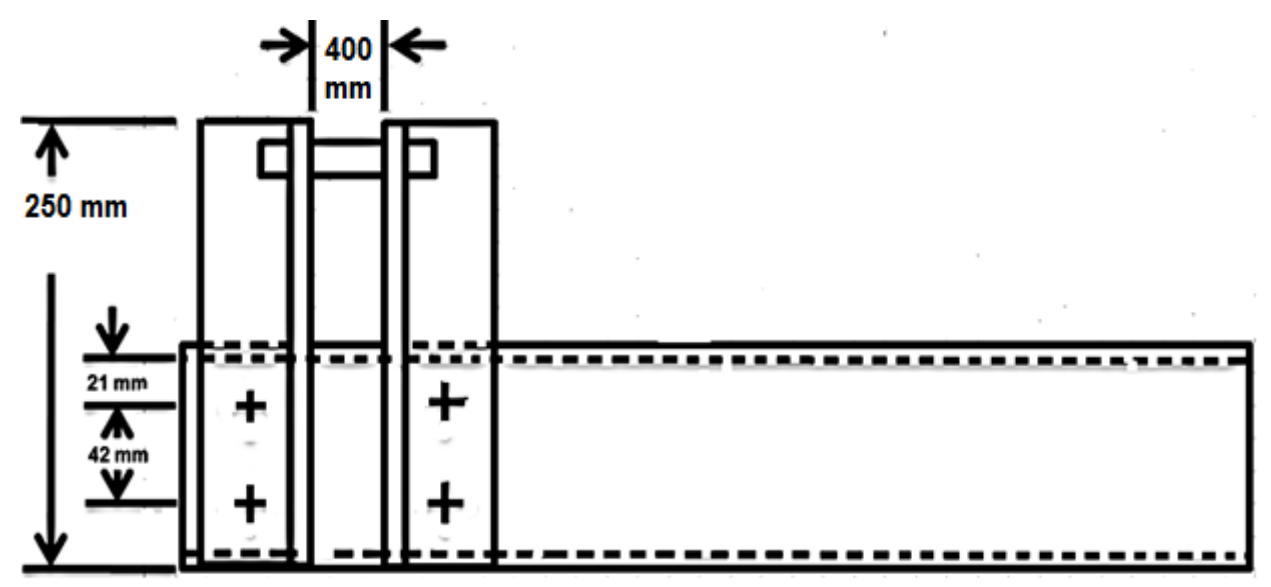

Fig. 2. Tine holder and linkage plats.

\section{6- Core Tine:}

Core tine (fig.3) was fabricated from steel 1042 with three diameters $1.27,1.9$ and $2.54 \mathrm{~cm}$. 


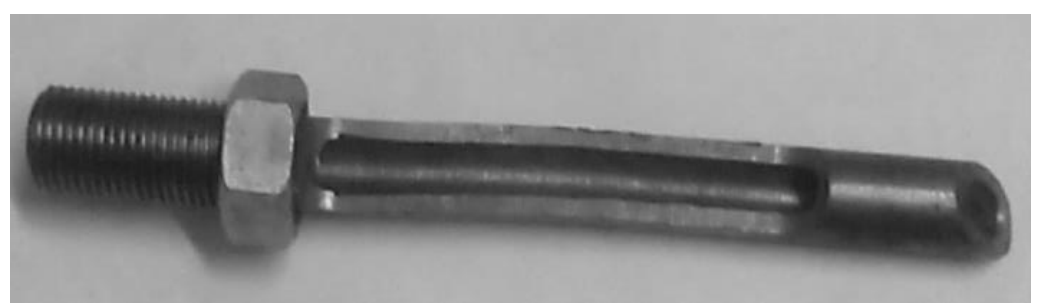

Fig.3. The core tine.

\section{7- Flexible linkage:}

The main aim of this linkage is to produce neat holes in the ground surface, when the tine engaged to soil with tractor motion it is allow for tine to scrape or damage the turf, this problem of engagement the ground is particularly acute in aeration having resilient restraining mechanisms that allow some shifting of tine when the tine is lifted out of the ground during operation.

\section{a- Body of linkage:}

The body of linkage (fig.4) Consists of the horizontal beam (A) connected to frame of machine with two bolts and connected to vertical beam (B) with one point by axle to allow limited motion with extension helical spring (C) with two fixed point axle in body of device, and connected plate between vertical beam and tine holder with dimensions $36 * 5 * 1 \mathrm{~cm}$ and fixed with the tine holder beam by angle plate with dimensions $7 * 7 * 1 \mathrm{~cm}$.

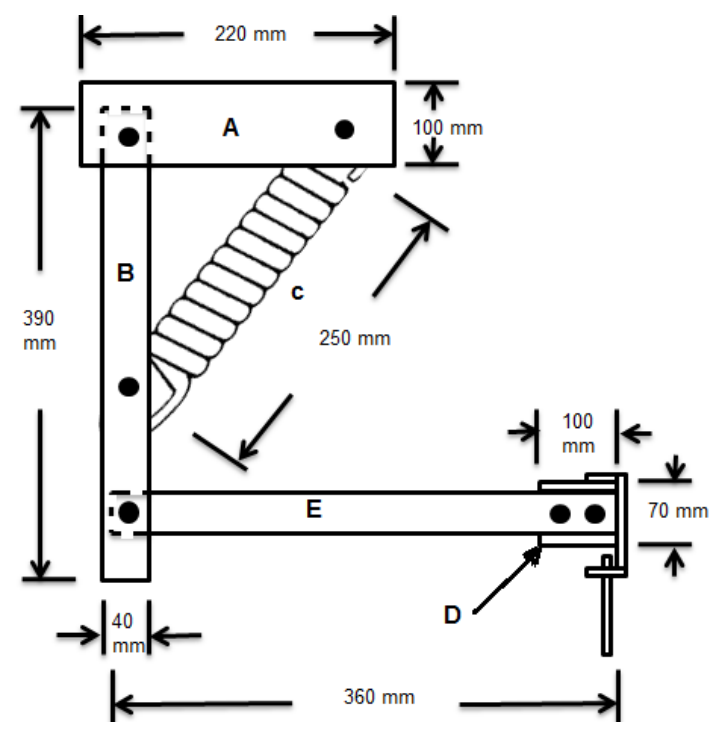

Fig.4. Content of flexible linkage. 


\section{3-1- Methods:}

The field study was initiated 2014 on turfgrass growing on a loamy sand soil and maintained under greens conditions. The studies were located at faculty of agriculture, Cairo University. A $3 \times 2 \times 3$ factorial arranged randomized complete block design with 4 replications. Treatments utilized were three tine diameter $(\mathrm{T})(1.27,1.9$ and $2.54 \mathrm{~cm})$ with at two depths (d) (5 and $8 \mathrm{~cm}$ ) with three operation speed (s) (1.5, 2 and 2.7 $\mathrm{cm})$.

\section{a- Laboratory tests :}

The soil physical properties such as soil moisture content, soil mechanical analysis and soil bulk density were measured before and after aeration operations as follows:

\section{1- Soil moisture content:}

The moisture content of the soil was determined using an electric oven adjusted to (105co) for 24 hours. Soil samples were taken at field through executing the different operation of turfgrass aeration (three replicates for each sample).and moisture was determine based on oven dry weight The soil moisture was calculated by using the following formula:

$$
\begin{aligned}
& \mathrm{S}_{\mathrm{m}}=\frac{\mathrm{W}-\mathrm{W}_{1}}{\mathrm{~W}} * 100 \% \\
& \text { Where: } \\
& \mathrm{W}=\text { mass of soil sample before dried, } \mathrm{g} . \\
& \mathrm{W} 1=\text { mass of the same soil sample after dried, } \mathrm{g} .
\end{aligned}
$$

\section{2- Soil bulk density:}

Soil samples were taken using cylindrical core sampler $\left(100 \mathrm{~cm}^{3}\right.$ volume $)$ Soil samples were taken at field through executing the different operation of turfgrass aeration (three replicates for each sample, to determine soil bulk density of soil samples which dried at $\left(105 c^{\circ}\right)$ for 24 hours.

The bulk density was calculated by using the following formula:

$$
\rho_{\mathrm{b}}=\frac{\mathrm{m}_{\mathrm{b}}}{\mathrm{v}_{\mathrm{b}}}
$$

Where:

$$
\rho_{\mathrm{b}}=\text { Soil bulk density, } \quad \mathrm{gm} . / \mathrm{cm}^{3} \text {. }
$$


$\mathrm{mb}=$ Dry weight of the soil in the container, $\mathrm{gm}$.

$\mathrm{vb}=$ Volume container, $\quad \mathrm{cm}^{3}$.

\section{3- Mechanical analysis:}

The soil mechanical analysis was carried out using the international method with $\mathrm{NH}_{4} \mathrm{OH}$ as dispersing agent piper.

\section{4- Soil porosity:}

Soil porosity (E) was calculated using the following formula:

$$
\begin{aligned}
& \mathrm{E}=\frac{\rho_{\mathrm{s}}-\rho_{\mathrm{b}}}{\rho_{\mathrm{s}}}=1-\frac{\rho_{\mathrm{b}}}{\rho_{\mathrm{s}}} \\
& \mathrm{E}=\text { soil porosity, } \% . \\
& \rho_{\mathrm{s}}=\text { real soil density, } \mathrm{gm} . / \mathrm{cm}^{3} .
\end{aligned}
$$

\section{5- Void ratio:}

Void ratio (e) was calculated using the following formula:

$\mathrm{e}=\frac{\rho_{\mathrm{s}}-\rho_{\mathrm{b}}}{\rho_{\mathrm{b}}}=\frac{\rho_{\mathrm{b}}}{\rho_{\mathrm{s}-1}}$

\section{b- Calculation of field capacity:}

The theoretical field capacity was calculated by using the following formula:

$$
\mathrm{TFC}=\frac{\mathrm{W} * \mathrm{~s} * 1000}{4200} \mathrm{fed} / \mathrm{h}
$$

Where:

$\mathrm{W}=$ working width of machine, $\mathrm{m}$.

$\mathrm{S}=$ average working forward speed, $\mathrm{Km} / \mathrm{h}$.

The actual field capacity (AFC) was calculated as follows:

$$
\mathrm{AFC}=\frac{1}{\text { Actual totl time in hours required per feddan }} \text { fed }
$$

The field efficiency $\left(\eta_{f}\right)$ wad calculated by using the following equation: $\eta_{\mathrm{f}}=\frac{\mathrm{AFC}}{\mathrm{TFC}} * 100 \%$ 


\section{c- Fuel consumption:}

The average fuel consumption in $\mathrm{L} / \mathrm{h}$ for different treatment of turfgrass aeration were estimated by measuring the decrease in fuel level in the tractor fuel tank after executing each operation, taking into consideration the actual consumed time.

\section{d- Energy consumption:}

To estimate the engine power during turfgrass aeration process, the decrease in fuel level accurately measuring immediately after each treatment. The following formula was used to estimate the engine power, (Embaby, 1985):

EP

$$
=\left[\text { f. c }\left(\frac{1}{3600}\right) \rho_{\mathrm{f}} * \text { L. C. } \mathrm{V} * 427 * \eta_{\mathrm{th}} * \eta_{\mathrm{m}} * \frac{1}{75}\right] \mathrm{KW}
$$

$\mathrm{EP}=$ Engine power,

$\mathrm{kW}$.

f. $\mathrm{c}=$ Fuel consumption,

$\mathrm{L} / \mathrm{h}$.

$\rho_{\mathrm{f}}=$ Density of fuel,

$0.85 \mathrm{~kg} / \mathrm{L}$.

L. C. V = Lower calorific value of fuel, $10.000 \mathrm{k} . \mathrm{cal} / \mathrm{kg}$.

$427=$ thermo- mechanical equivalent. Kg.m/ k.cal.

$\eta_{\mathrm{th}}=$ Thermal efficiency of the engine (35 for diesel).

$\eta_{\mathrm{m}}=$ Mechanical efficiency of the engine ( $83 \%$ for diesel).

Hence, the specific energy consumption can be calculated by following formula:

Energy consumption

$$
=\frac{\text { Engine power } \mathrm{kW}}{\text { Field capacity fed } / \mathrm{h}} \frac{\mathrm{kW} \cdot \mathrm{h}}{\text { fed }}
$$

\section{RESULTS AND DISCUSSION}

a- The effect of different turfgrass aeration treatments on bulk

\section{density of the soil:}

From data in (figs 5, 6) it's shown treatments of turfgrass aeration decreased the values of bulk density than the value at no aeration treatment $(1.086 \mathrm{gm} / \mathrm{cm} 3)$, the percentage of mean relative decrease of 
bulk density as a results of applying turfgrass aeration this may be due to the effect of depth of thatch layer, tine diameter and forward speed.

Considering the working speed and depth for each treatment, It is noticed that bulk density at $5 \mathrm{~cm}$ depth (fig 5) is influenced by aeration speed up and down, treatments with first diameter $(1.27) \mathrm{cm}$ was lower value of the bulk density with the first speed $1.5 \mathrm{~km} / \mathrm{h} \quad(0.796 \mathrm{~g} / \mathrm{cm} 3)$. The second treatment with the second diameter $(1.9 \mathrm{~cm})$ was decreased bulk density with increasing forward speed $1.5,2$ and $2.7 \mathrm{~km} / \mathrm{h}$ respectively and the third diameter $(2.54 \mathrm{~cm})$ was increasing bulk density with increasing forward speed.

It is noticed that bulk density at 8cm depth (fig. 6) was influenced by aeration speed up and down, where the treatments with first diameter $(1.27 \mathrm{~cm})$ was increasing soil bulk density with the second speed $2 \mathrm{~km} / \mathrm{h}$ while decreasing with the first $1.5 \mathrm{~km} / \mathrm{h}$ and third speed $2.7 \mathrm{~km} / \mathrm{h}$ and the lower value of the bulk density was with the first speed $1.5 \mathrm{~km} / \mathrm{h}(0.780$ $\mathrm{g} / \mathrm{cm} 3)$, Similarly the second treatment with the second diameter $(1.9 \mathrm{~cm})$ and the third diameter $(2.54 \mathrm{~cm})$.

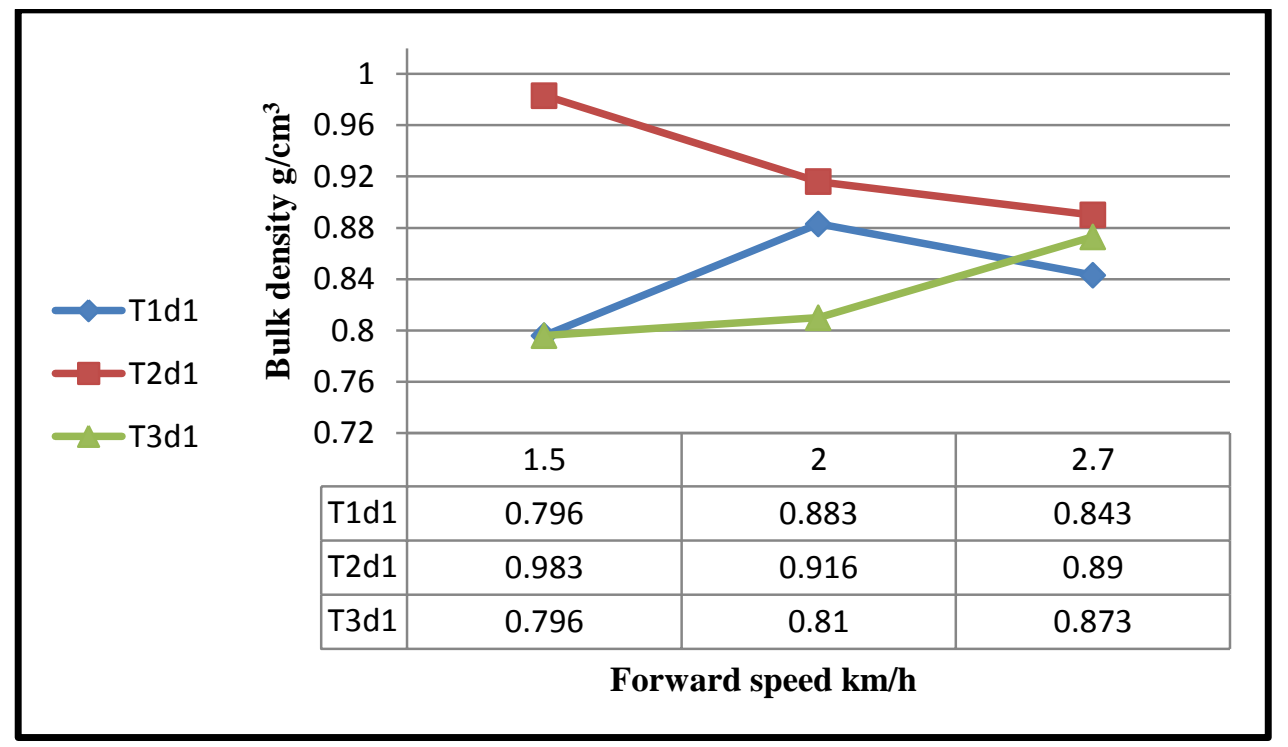

Fig 5. Mean bulk density of the soil for different turfgrass aeration treatments at $5 \mathrm{~cm}$ depth. 


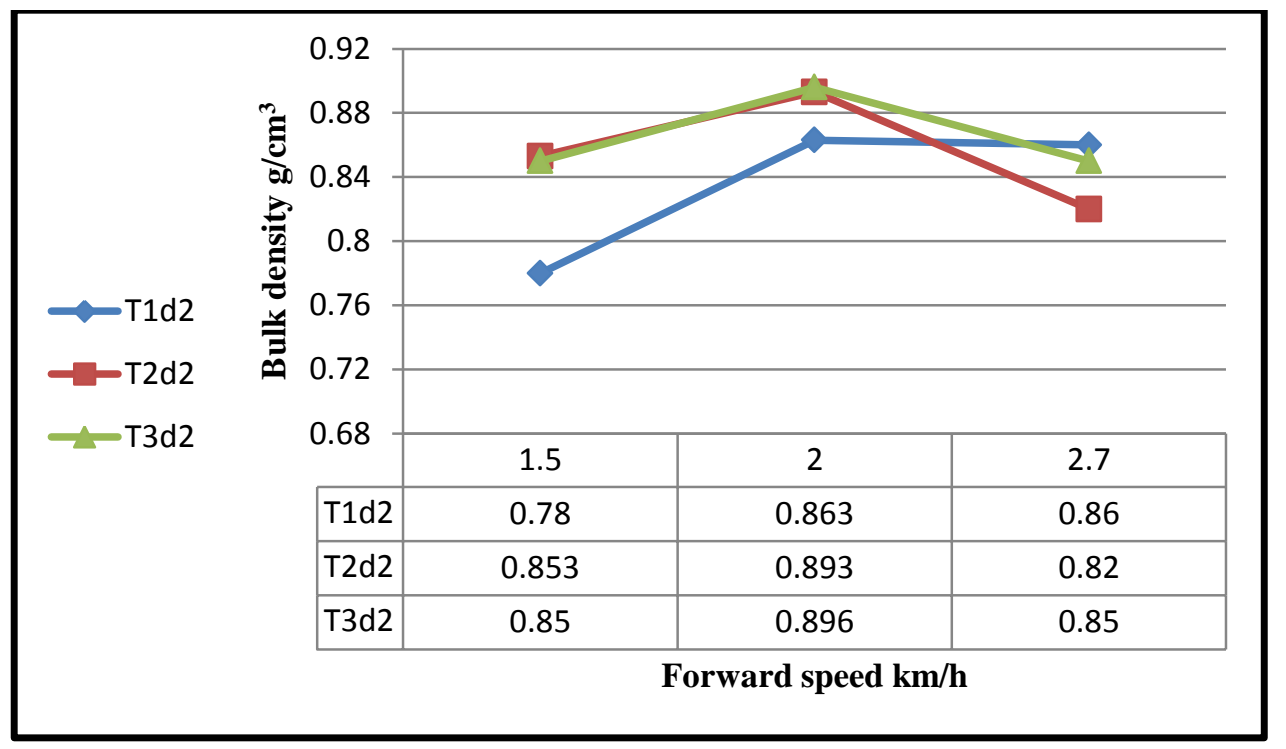

\section{Fig 6. Mean bulk density of the soil for different turfgrass aeration treatments at $8 \mathrm{~cm}$ depth.}

According to statistical analysis the effective treatment was $0.780 \mathrm{~g} / \mathrm{cm} 3$ with first diameter $1.27 \mathrm{~cm}$ at second depth $8 \mathrm{~cm}$ with first speed $1.5 \mathrm{~km} / \mathrm{h}$. the effective speed for the first diameter $(1.27 \mathrm{~cm})$ and third diameter $(2.54 \mathrm{~cm})$ was $1.5 \mathrm{~km} / \mathrm{h}$ and for the second diameter was $2.7 \mathrm{~km} / \mathrm{h}$. The effective depth was $8 \mathrm{~cm}$ for first diameter $(1.27 \mathrm{~cm})$ and second diameter $(1.9 \mathrm{~cm})$ and the effective depth was $5 \mathrm{~cm}$ for third diameter $(2.54 \mathrm{~cm})$ and the effective diameter for the second depth was $1.27 \mathrm{~cm}$.

\section{b- The effect of different turfgrass aeration treatments on Void ratio:}

From (fig. 7, 8). It is noticed the change in void ratio a result of turfgrass aeration with $5 \mathrm{~m}$ depth is equal to $1.890,1.603$ and 1.730 for first diameter $(1.27 \mathrm{~cm})$ with three forward speed $1.5,2$ and $2.7 \mathrm{~km} / \mathrm{h}$. respectively, the value of void ratio with the second diameter $(1.9 \mathrm{~cm})$ was $1.340,1.510$ and 1.583 with forward speed $1.5,2$ and $2.7 \mathrm{~km} / \mathrm{h}$. respectively and third diameter $(2.54 \mathrm{~cm})$ has decreasing void ratio 1.893 , 1.583 and 1.630 with forward speed $1.5,2$ and $2.7 \mathrm{~km} / \mathrm{h}$ respectively.

It is clear that (Fig.8) the change in void ratio as a result of turfgrass aeration at $8 \mathrm{~cm}$ depth is equal to $1.950,1.660$ and 1.673 for first 
diameter $(1.27 \mathrm{~cm})$ with three forward speed 1.5, 2 and $2.7 \mathrm{~km} / \mathrm{h}$ respectively, the second diameter $(1.9 \mathrm{~cm})$ was $1.696,1.573$ and 1.803 with forward speed 1.5, 2 and $2.7 \mathrm{~km} / \mathrm{h}$ respectively and third diameter $(2.54 \mathrm{~cm})$ was $1.706,1.563$ and 1.706 with forward speed 1.5, 2 and 2.7 $\mathrm{km} / \mathrm{h}$ respectively.

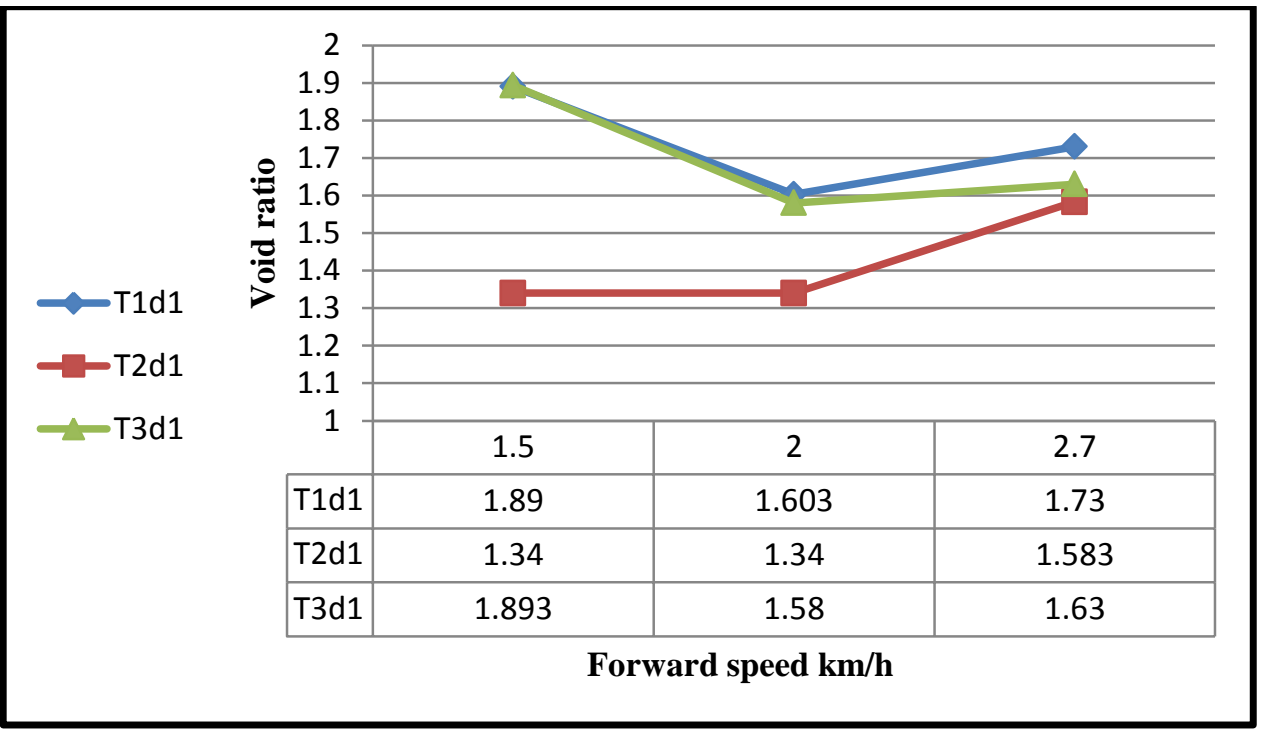

Fig 7. Mean void ratio of the soil for different turfgrass aeration treatments at $5 \mathrm{~cm}$ depth

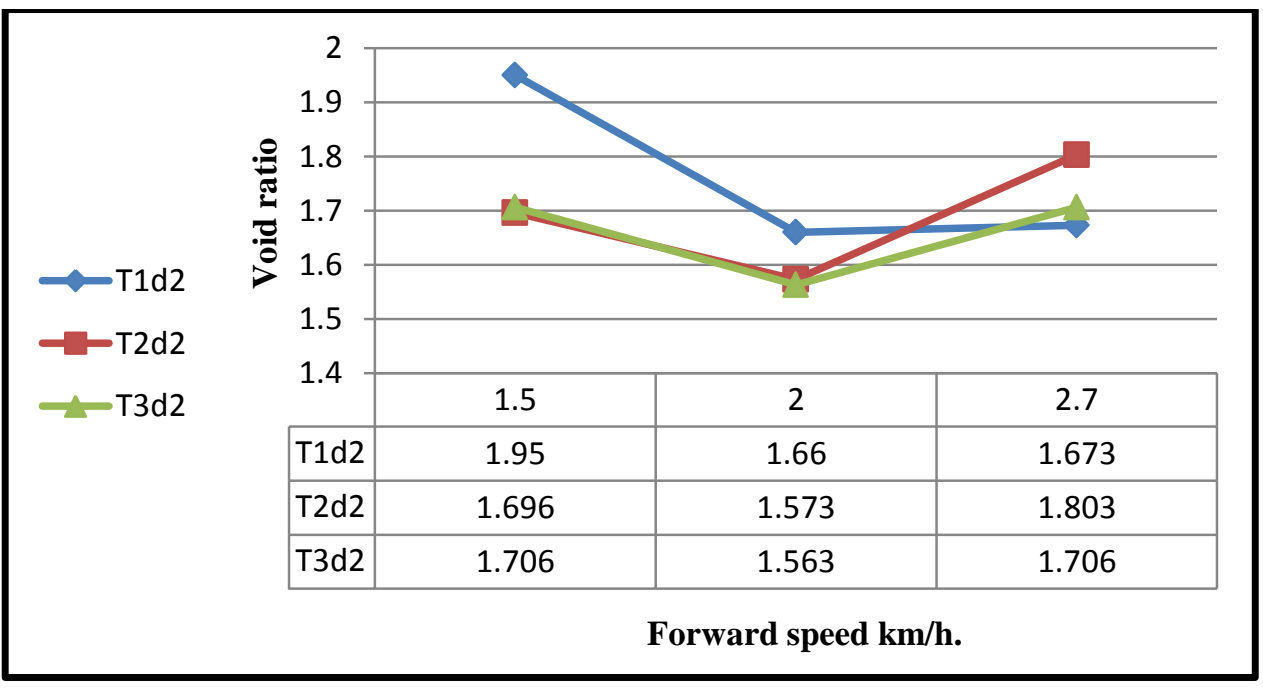

Fig 8. Mean void ratio of the soil for different turfgrass aeration treatments at $8 \mathrm{~cm}$ depth. 


\section{c- The effect of different turfgrass aeration treatments on soil porosity:}

Soil porosity is a function of bulk density and it change with change of bulk densities, the higher bulk densities value will meet the lower value of the soil porosity.

The change in soil porosity at $5 \mathrm{~cm}$ (fig.9) was equal to $65.363,61.593$ and $63.333 \%$ for first diameter $(1.27 \mathrm{~cm})$ with forward speed $1.5,2$ and $2.7 \mathrm{~km} / \mathrm{h}$ respectively, the second diameter $(1.9 \mathrm{~cm})$ had change in soil porosity $57.247,60.147$ and $61.303 \%$ with forward speed 1.5, 2 and 2.7 $\mathrm{km} / \mathrm{h}$ respectively and the third diameter $(2.54 \mathrm{~cm})$ had change in soil porosity $65.363,64.783$ and $62.027 \%$ with forward speed $1.5,2$ and 2.7 $\mathrm{km} / \mathrm{h}$ respectively .

It is clear that the change in total porosity as a result of turfgrass aeration at depth $8 \mathrm{~cm}$ (fig. 10) was equal to 66.090, 62.4630 and $62.610 \%$ for first diameter $(1.27 \mathrm{~cm})$ with forward speed $1.5,2$ and $2.7 \mathrm{~km} / \mathrm{h}$ respectively, the second diameter $(1.9 \mathrm{~cm})$ has change in soil porosity $62.897,61.157$ and $64.347 \%$ with forward speed $1.5,2$ and $2.7 \mathrm{~km} / \mathrm{h}$ respectively and the third diameter $(2.54 \mathrm{~cm})$ has change in soil porosity $63.043,61.010$ and $63.043 \%$ with forward speed $1.5,2$ and $2.7 \mathrm{~km} / \mathrm{h}$ respectively.

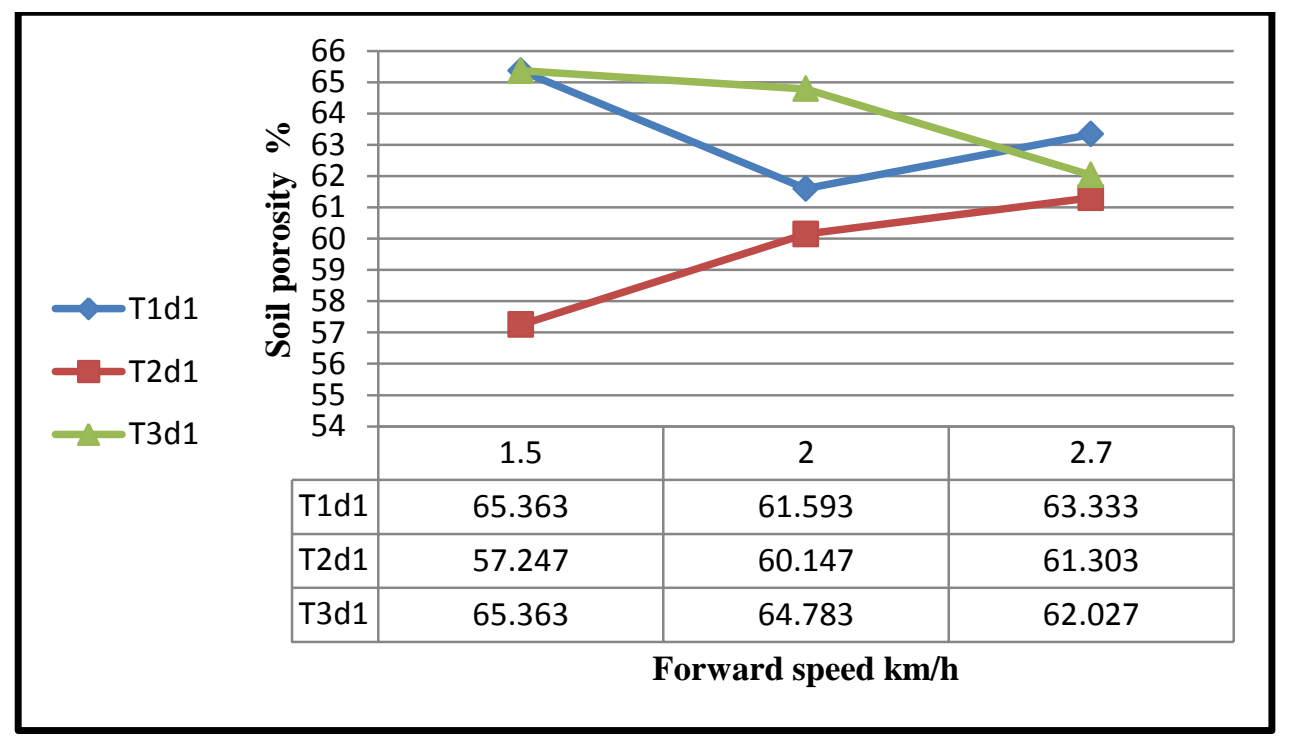

Fig 9. Mean soil porosity of the soil for different turfgrass aeration treatments at $5 \mathrm{~cm}$ depth. 


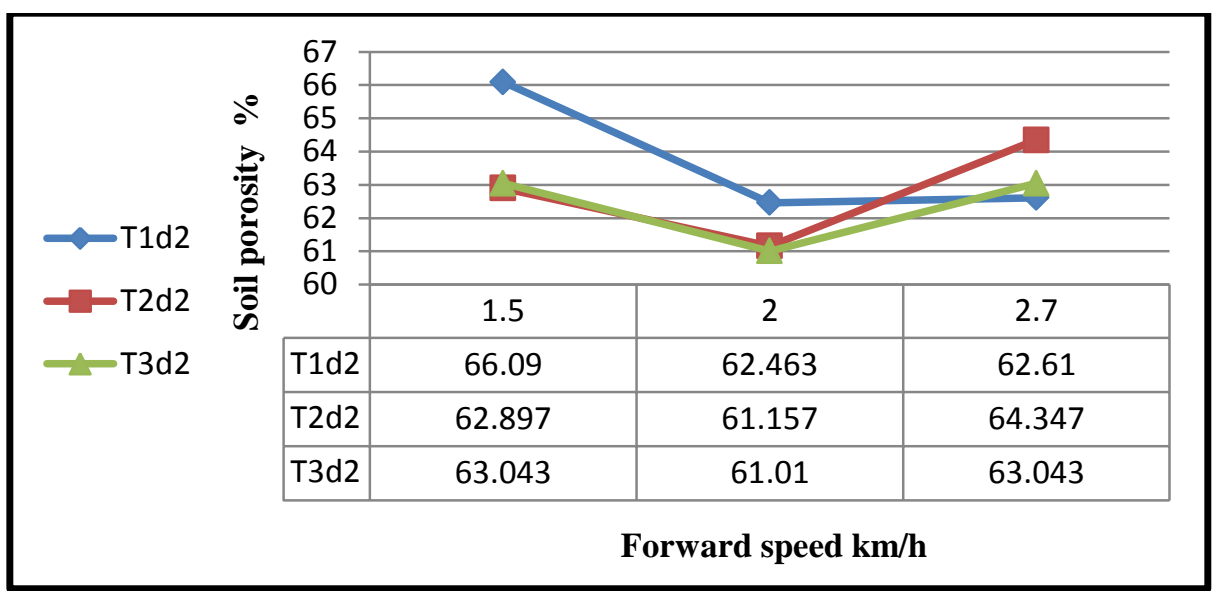

\section{Fig 10. Mean soil porosity of the soil for turfgrass aeration treatments at $8 \mathrm{~cm}$ depth}

d- The performance of different treatments for aeration turfgrass:

1- Field capacity of turfgrass aeration treatment :

From the data presented in (fig.11) it is noticed that: the field capacity at first depth $5 \mathrm{~cm}$ and with the first forward speed $1.5 \mathrm{~km} / \mathrm{h}$. was equal $0.377,0.373$ and $0.375 \mathrm{fed} / \mathrm{h}$ with the first $(1.27 \mathrm{~cm})$, second $(1.9 \mathrm{~cm})$ and third $(2.54 \mathrm{~cm})$ diameter respectively, the value of field capacity with the second forward speed $2 \mathrm{~km} / \mathrm{h}$ was $0.503,0.497$ and $0.497 \mathrm{fed} . / \mathrm{h}$. for the first $(1.27 \mathrm{~cm})$, second $(1.9 \mathrm{~cm})$ and third $(2.54 \mathrm{~cm})$ diameter respectively and the third forward speed $2.7 \mathrm{~km} / \mathrm{h}$. has actual field capacity equal $0.683,0.670$ and $0.687 \mathrm{fed} / \mathrm{h}$ for the first $(1.27 \mathrm{~cm})$, second $(1.9 \mathrm{~cm})$ and third $(2.54 \mathrm{~cm})$ diameter respectively.

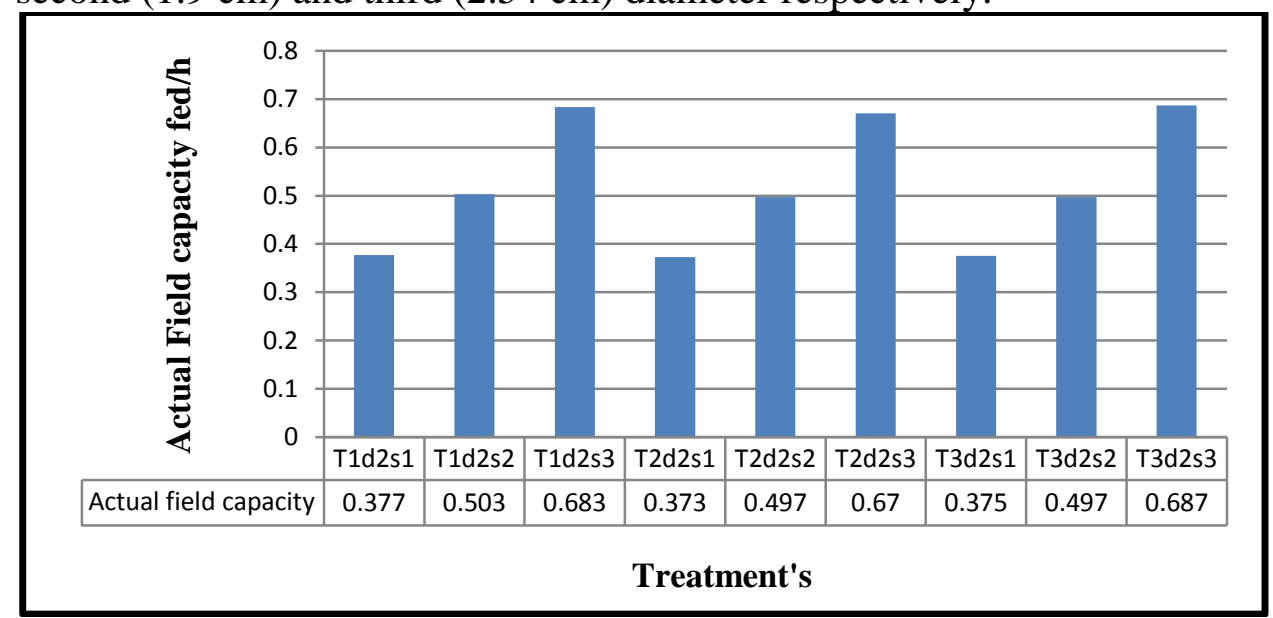

Fig 11. Mean field capacity of different treatments for aeration turfgrass at $5 \mathrm{~cm}$ depth. 


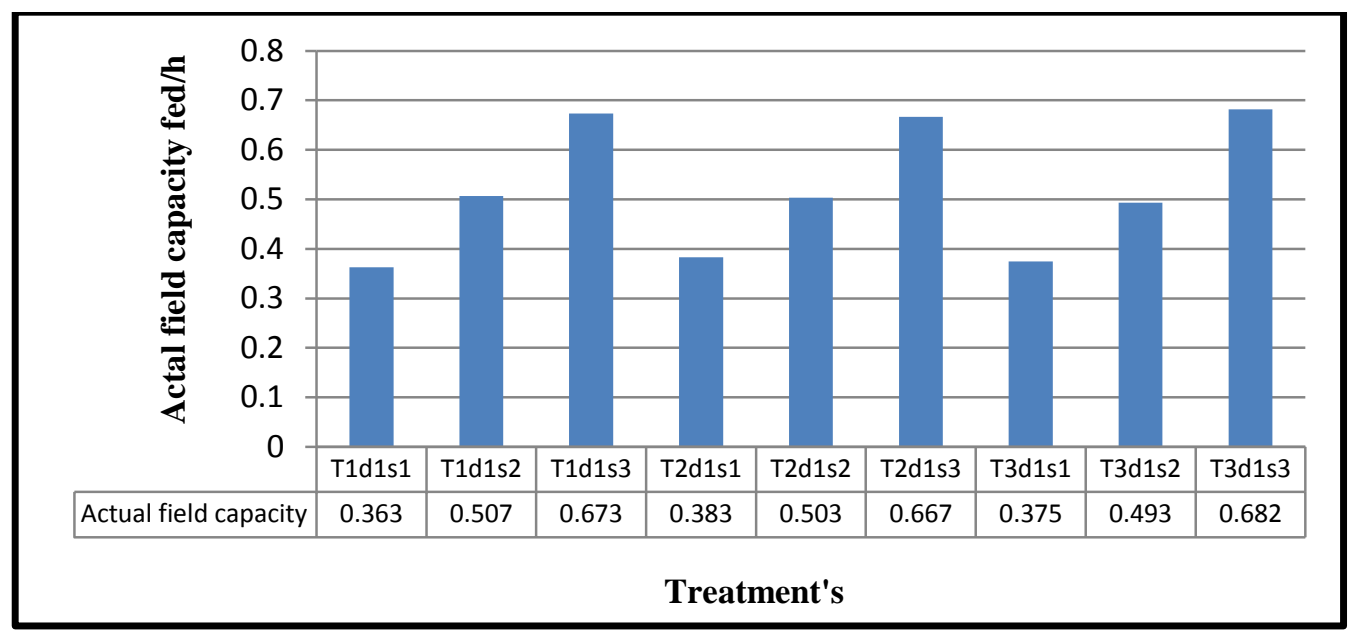

Fig 12. Mean field capacity of different treatments for aeration turfgrass at $8 \mathrm{~cm}$ depth.

From the data presented in (fig.12) it is clear that: the field capacity at depth $8 \mathrm{~cm}$ and with the first forward speed $1.5 \mathrm{~km} / \mathrm{h}$ was equal 0.363 , 0.383 and $0.375 \mathrm{fed} / \mathrm{h}$ with the first $(1.27 \mathrm{~cm})$, second $(1.9 \mathrm{~cm})$ and third $(2.54 \mathrm{~cm})$ diameter respectively, the value of field capacity with the second forward speed $2 \mathrm{~km} / \mathrm{h}$ was $0.507,0.503$ and $0.493 \mathrm{fed} / \mathrm{h}$ for the first $(1.27 \mathrm{~cm})$, second $(1.9 \mathrm{~cm})$ and third $(2.54 \mathrm{~cm})$ diameter respectively and the third forward speed $2.7 \mathrm{~km} / \mathrm{h}$ had actual field capacity equal $0.673,0.667$ and $0.682 \mathrm{fed} / \mathrm{h}$ for the first $(1.27 \mathrm{~cm})$, second $(1.9 \mathrm{~cm})$ and third $(2.54 \mathrm{~cm})$ diameter respectively.

\section{2- The effect of turfgrass aeration treatments on fuel consumption :}

The fuel consumption was measured after executing all treatments of turfgrass aeration from the results shown in (fig. 13, 14):

It is noticed that the fuel consumption was increased with increasing diameter of tine, depth and forward speed and the higher treatment in consumed fuel was $5.78 \mathrm{~L} / \mathrm{h}$ with the third diameter $(2.54 \mathrm{~cm})$ at $8 \mathrm{~cm}$ depth and $2.7 \mathrm{~km} / \mathrm{h}$ forward speed.

From (fig. 13) it is noticed that the first tine diameter $(1.27 \mathrm{~cm})$ had the lowest fuel consumption at $5 \mathrm{~cm}$ depth and for all treatments. 


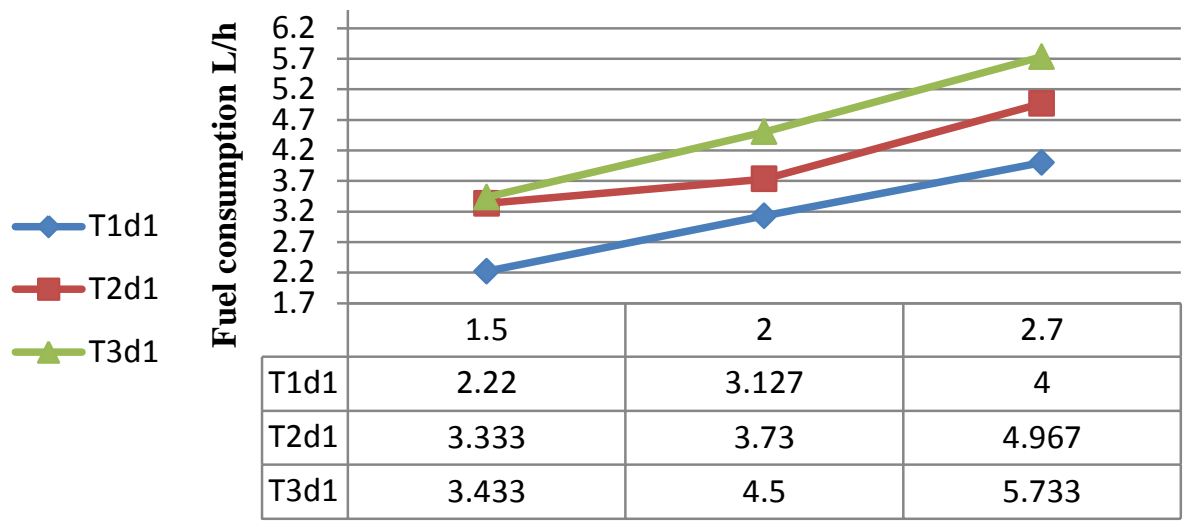

Forward speed km/h

Fig 13. Mean fuel consumption of different treatments for aeration turfgrass at $5 \mathrm{~cm}$ depth.

From (fig. 14) it is noticed that the first tine diameter $(1.27 \mathrm{~cm})$ had the lower fuel consumption at $8 \mathrm{~cm}$ depth and the fuel consumption for second tine diameter $(1.9 \mathrm{~cm})$ is medium, while the third diameter $(2.54 \mathrm{~cm})$ had the higher value of fuel consumption $5.78 \mathrm{~L} / \mathrm{h}$.

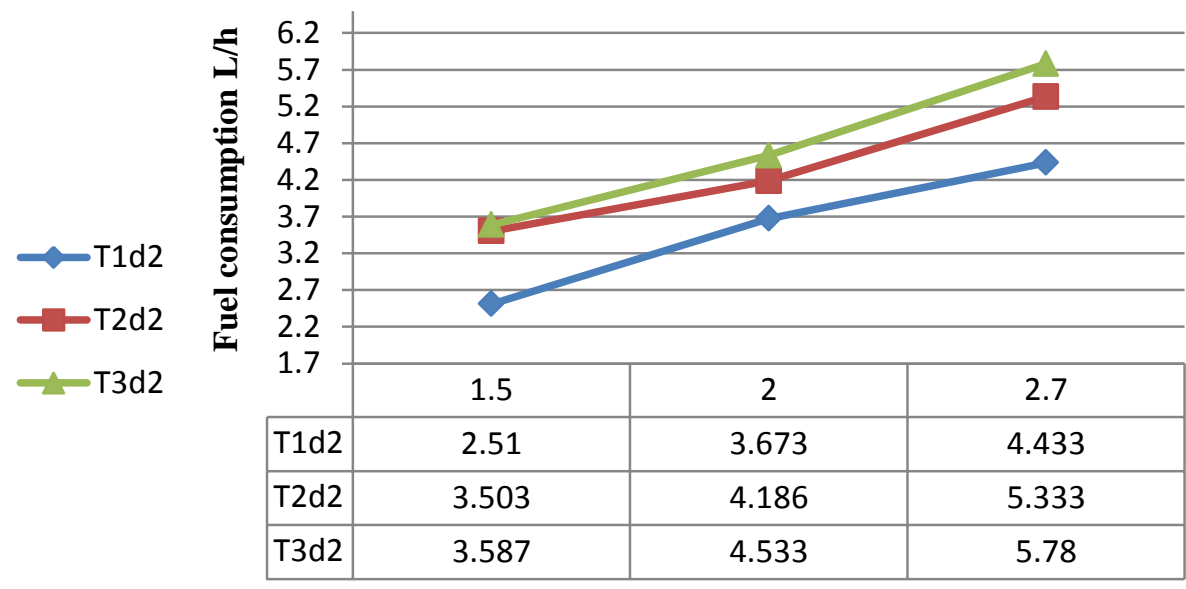

Forward speed km/h

Fig 14. Mean fuel consumption of different treatments for aeration turfgrass at $8 \mathrm{~cm}$ depth. 


\section{3- The effect of turfgrass aeration treatments on energy consumption:}

The energy consumption was calculated for all treatments of aeration turfgrass and shown in (fig. 15, 16):

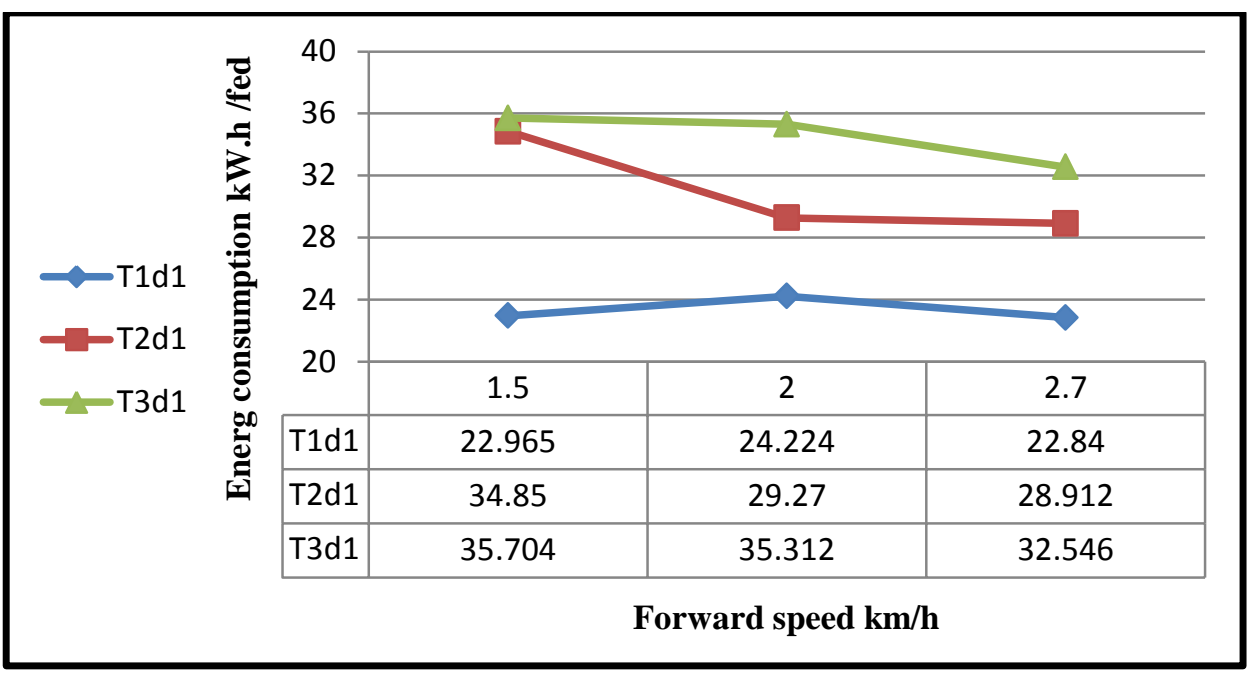

Fig 15. Mean energy consumption for different turfgrass aeration treatments at $5 \mathrm{~cm}$ depth.

from (fig. 15) shown the behavior of energy consumption for different treatments at $5 \mathrm{~cm}$ depth and it is noticed the higher value was 35.704 $\mathrm{kW} . \mathrm{h} / \mathrm{fed}$ with the third diameter $(2.54 \mathrm{~cm})$ with first speed $1.5 \mathrm{~km} / \mathrm{h}$. and the lowest value was $22.84 \mathrm{~kW} . \mathrm{h} /$ fed for the first tine diameter $(1.27$ $\mathrm{cm}$ ) with third forward seed $2.7 \mathrm{~km} / \mathrm{h}$.

From (fig.16) The energy consumption with the first diameter $(1.27 \mathrm{~cm})$ had the lower value at $8 \mathrm{~cm}$ depth and the value of energy consumption was $26.967,28.254$ and $25.689 \mathrm{~kW} . \mathrm{h} /$ fed with three forward speed 1.5, 2 and $2.7 \mathrm{~km} / \mathrm{h}$. this trend for actual field capacity and it is clear that the energy consumed value for the second tine diameter $(1.9 \mathrm{~cm})$ and third tine diameter $(2.54 \mathrm{~cm})$ decreased with increasing the forward speed. The third tine diameter had the higher value for energy consumption 37.305, 35.860 and $33.053 \mathrm{~kW} . \mathrm{h} /$ fed with forward speed $1.5,2$ and $2.7 \mathrm{~km} / \mathrm{h}$. 


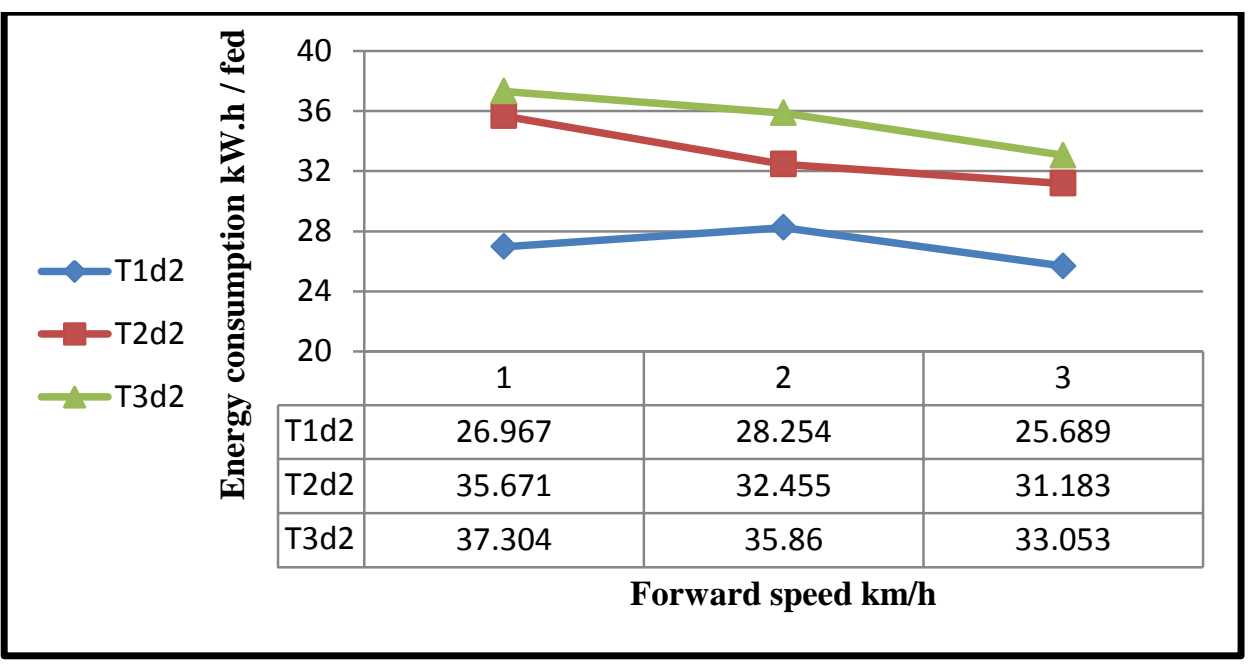

\section{Fig 16. Mean energy consumption for different treatments for aeration turfgrass at $8 \mathrm{~cm}$ depth.}

\section{CONCLUSION}

The following conclusions were made from the study:

- Bulk density decreased for all treatments, while the effective treatment was $0.780 \mathrm{~g} / \mathrm{cm}^{3}$ at with $8 \mathrm{~cm}$ depth, tine diameter $1.27 \mathrm{~cm}$ and forward speed $1.5 \mathrm{~km} / \mathrm{h}$ compared to control value $\left(1.086 \mathrm{~g} / \mathrm{cm}^{3}\right)$.

- The void ratio increased for all treatments, while the high increasing value was 1.950 at $8 \mathrm{~cm}$ depth, tine diameter $1.27 \mathrm{~cm}$ and forward speed $1.5 \mathrm{~km} / \mathrm{h}$.

- The soil porosity increased for all treatments, and the effective treatment from variance analysis was $\mathrm{T}_{1} \mathrm{~d}_{2} \mathrm{~s}_{1}$ at $8 \mathrm{~cm}$ depth, tine diameter $1.27 \mathrm{~cm}$ and forward speed $1.5 \mathrm{~km} / \mathrm{h}$. and it was value 66.09 $\%$.

- The highest value of field capacity was $0.687 \mathrm{fed} / \mathrm{h}$ with third diameter $2.54 \mathrm{~cm}$ at $5 \mathrm{~cm}$ depth with $2.7 \mathrm{~km} / \mathrm{h}$.

- It is noticed that the fuel consumption was increased with increasing diameter of tine, depth and forward speed and the higher treatment in consumed fuel was $5.78 \mathrm{~L} / \mathrm{h}$ with the third diameter $2.54 \mathrm{~cm}$ at $8 \mathrm{~cm}$ depth and $2.7 \mathrm{~km} / \mathrm{h}$.

- It was found that $\mathrm{T}_{1} \mathrm{~d}_{1} \mathrm{~s}_{3}$ tine diameter $1.27 \mathrm{~cm}$ at depth $8 \mathrm{~cm}$ and forward speed $2.7 \mathrm{~km} / \mathrm{h}$ was the lowest energy consumption for turfgrass aeration $(22.840 \mathrm{~kW} . \mathrm{h} / \mathrm{fed}$. 


\section{REFERENCE}

Abrougui, K.; Chehaibi, S. and Khelifi, M.(2013). Effects of working depth on mechanical aeration of a grassy soil and its impact on the plant root behavior. Herald Journal of Agriculture and Food Science Research , 2 (1): 063 - 069.

Akram, M. and Kemper, W.D.(1979). Infiltration of soils as affected by the pressure and water content at the time of compaction. Soil Sci. Soc. Am. J., 43:1080-1086.

ASABE Stsndards (2006). Three Point Free Link Attachment for Hitching Implements to Agricultural Wheel Tractors. American Society of Agricultural and Biological Engineers.

Beard, J. B. (1973). Turfgrass science and culture. Prentice-Hall Inc. Englewood Cliffs, New Jersey, USA.

Bruneau, A.; Cooper,R. and Reynolds, C.(2004). Effective Renovation of Bermudagrass Athletic Fields. Green Light on Sports Turf. Turfgrass Council of North Carolina.USA.

Bunnell, B.T.; McCarty, L.B. and Hill, H.S.(2001). Summer cultivation effects on a sand based creeping bentgrass golf green. Intl. Turfgrass Soc. Res. J., 9:3-9.

Childs ,R. P.( 2004) . Mechanical Design. Elsevier. Amsterdam.

Dawidowsky, J.B. and Koden, A.J.(1987). Changes in soil water suction, conductivity and dry strength during deformation of wet undisturbed samples. Soil Tillage Res., 9:169-180.

Embaby,A.T. (1985). A comparison of the different mechanization system for career crop production. M. SC. Thesis . Agric., Eng. Dept. Faculty of agriculture. Cairo university.

Hillel, D.(1980). Introduction to Soil Physics. Academic Press, London.

Khurmi, R. S. and Gupta, J. K. (2005). Machine Design . Eurasia Publishing House . New Delhi, India.

Libardi, P. L.; Teichardt, K.; Jose, C. ; Bazza, M. and Nielsen, D.R. (1976). An approximated method of estimating soil water diffusivity for different soil bulk densities. Water Resour. Res., 18:177-181.

Linn, D.M. and Doran, J.W.(1984). Effect of water-filled pore space on carbon dioxide and nitrous oxide. Soil Sci. Soc. Am. J., 48:12671272. 
Lodge, G. M.; Robinson, G. G. and Simpson, P. C. (1990). Grasses native and naturalised - recognition value, distribution. Agfact $\mathrm{P}$ 25.32 .

McCarty, L.B.; Gregg, M.F. and Toler, J. E.( 2007). Thatch and mat management in an established creeping bentgrass golf green. Agron. J., 99:1530-1537.

Meek, B. D.; Rechel, L. M.; Carter, L. M. and Detar, W. R.(1992). Bulk density of a sandy loam: traffic, tillage, and irrigation-method effects. Soil Sci. Soc. Am. J., 56:562-565.

Shippen J. M.; Ellin C. R. and Clover C. H.(1980). Basic Farm Machinery, Third Edition. Pergamon Press. Oxford, UK.

Sills, M. J. and Carrow, R. N. (1983). Turfgrass Growth, N Use, and Water Use under Soil Compaction and N Fertilization. Agron. J., 75(3): 488-492.

Sorokovsky, P.; Krzic, M.and Novak, M.D.(2007). Core aeration of sand-based putting greens in the Lower Fraser Valley of British Columbia. Canadian J. of Soil Sci., 87:103-111.

Turgeon, A. J. (2002). Turfgrass Management. 5th ed. Penn State University. Pennsylvania, USA.

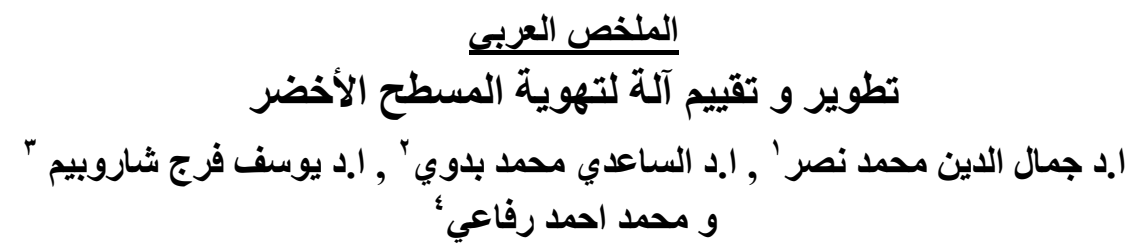

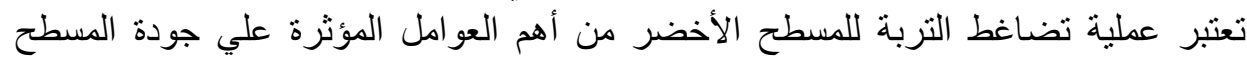

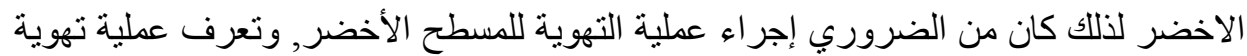



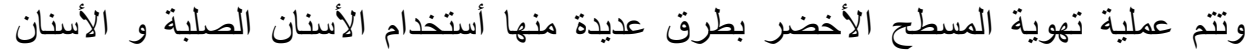



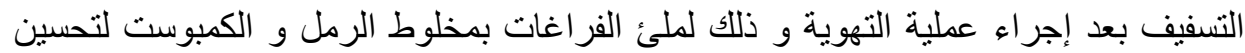



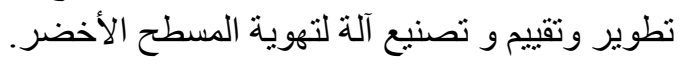

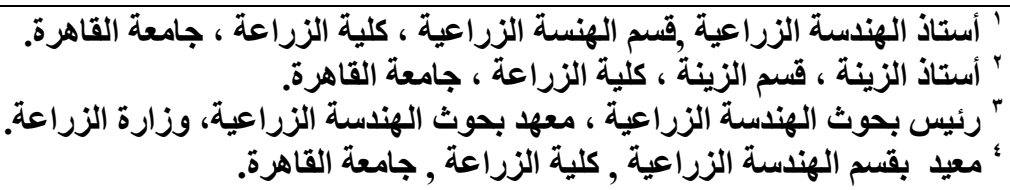


ولتحقيق ذلك الهدف تم تطوير وتصنيع آلة تتكون من الاطار و نظام الشبك و مجموعة نقل

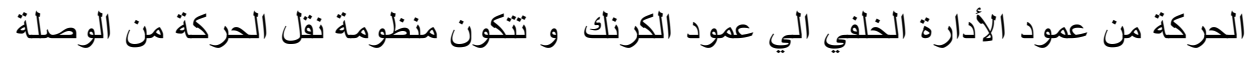

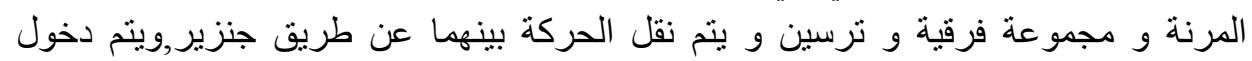

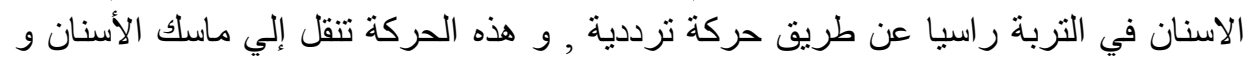

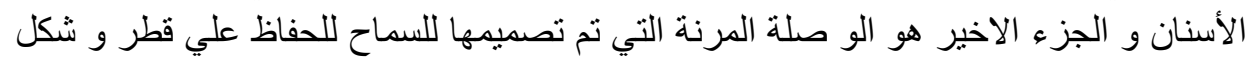
الثقوب في التربة أثناء حركة الجرار مع ظروف التشغيل المختلفة.

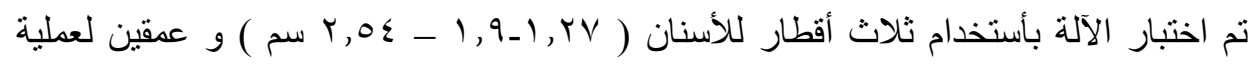

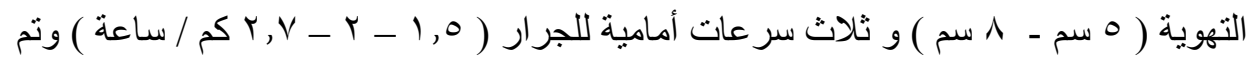

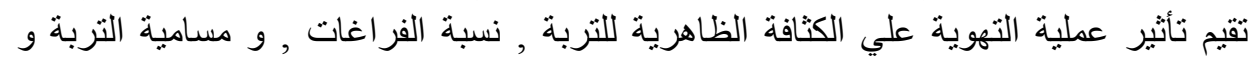

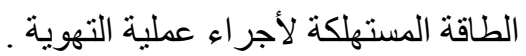



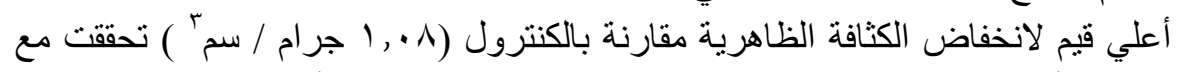

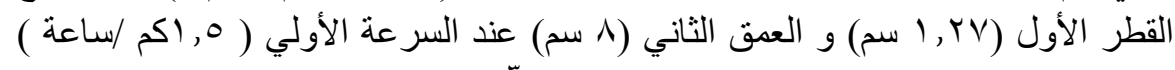

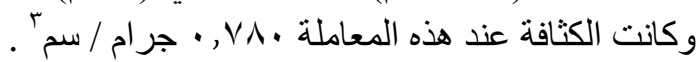

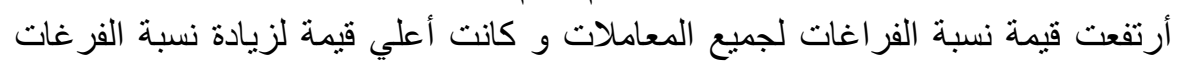

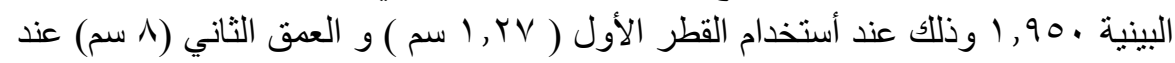

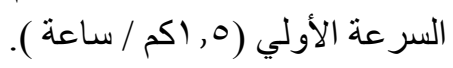

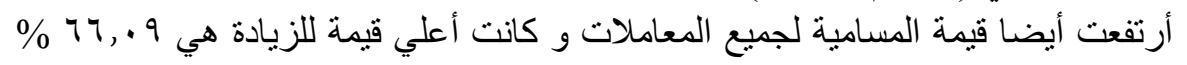

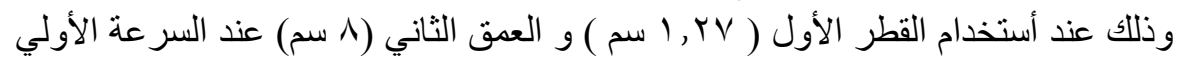

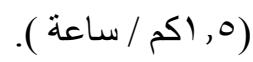


العمق الأول (0سم) و السرعة الثالثة ( r,V كم / ساعة ) ).

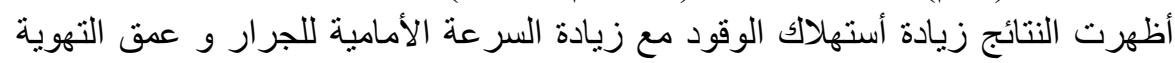



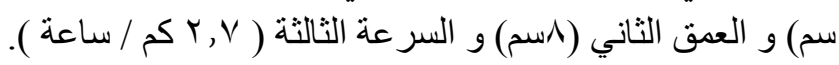

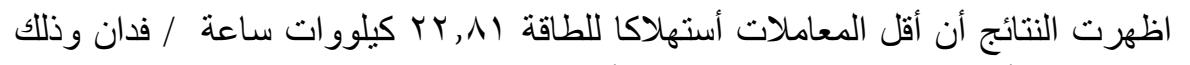



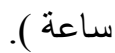

\section{ومن خلال النتائج تم التوصل إلي:}

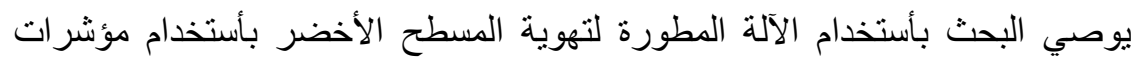

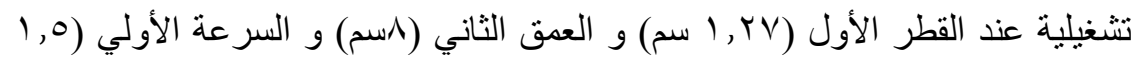



